\title{
Incremental validity of positive orientation: predictive efficiency beyond the five-factor model
}

\begin{abstract}
BACKGROUND
The relation of positive orientation (a basic predisposition to think positively of oneself, one's life and one's future) and personality traits is still disputable. The purpose of the described research was to verify the hypothesis that positive orientation has predictive efficiency beyond the five-factor model.
\end{abstract}

\section{PARTICIPANTS AND PROCEDURE}

One hundred and thirty participants (at the mean age $M=24.84$ ) completed the following questionnaires: the Self-Esteem Scale (SES), the Satisfaction with Life Scale (SWLS), the Life Orientation Test-Revised (LOT-R), the Positivity Scale (P-SCALE), the NEO Five Factor Inventory (NEO-FFI), the Self-Concept Clarity Scale (SCC), the Generalized Self-Efficacy Scale (GSES) and the Life Engagement Test (LET).

\section{RESULTS}

The introduction of positive orientation as an additional predictor in the second step of regression analyses led to better prediction of the following variables: purpose in life, self-concept clarity and generalized self-efficacy. This effect was the strongest for predicting purpose in life (i.e. $14 \%$ increment of the explained variance).

\section{CONCLUSIONS}

The results confirmed our hypothesis that positive orientation can be characterized by incremental validity - its inclusion in the regression model (in addition to the five main factors of personality) increases the amount of explained variance. These findings may provide further evidence for the legitimacy of measuring positive orientation and personality traits separately.

\section{KEY WORDS}

incremental validity; Big Five; purpose in life; positive orientation; five-factor model 


\section{BACKGROUND}

The flourishing positive psychology movement has inspired broad research on the determinants of human optimal functioning (Snyder \& Lopez, 2002; Donaldson, Dollwet, \& Rao, 2015). Personality, understood as a rather stable and unique constellation of traits, may be treated as an immense predictor of different behaviors, including 'positive' ones, i.e. those accounting for optimal functioning and fostering health (Sheldon, Cheng, \& Hilpert, 2011; Borgen \& Lindley, 2003). However, at the theoretical level, it is not so easy to find the so-called 'positivity' in a widely accepted five-factor model (FFM) (McCrae \& Costa, 1987; Caprara, 2010). The five major personality factors cannot be indisputably recognized positive (arguably with the exception of emotional stability, which is treated as a better pole for neuroticism) as they may translate to both good and bad performance and adjustment (McCrae \& Costa, 2003). For example, it is generally approved to be agreeable and friendly, but it may also make other people take advantage of you (see also: Egan, Piek, \& Dyck, 2015). It is also positively valued to work hard and conscientiously, but there is a hidden risk of feeling overworked and having problems with work-life balance (Chen-Ming \& Ying-Wen, 2009). Openness may be a burden as well - e.g. in the case when you have to do an ordinary, boring job; it also seems to be a risk factor of gambling disorder (Carlotta et al., 2015). Extraversion - a trait that includes positive emotionality (McCrae \& Costa, 1987) - should also be treated with caution, as it is not introversion which predicts negative emotionality, but neuroticism (i.e. high introversion does not mean negative emotionality, which is somewhat positive itself; see also: Cain, 2012).

According to Caprara (2010), the mentioned underrepresentation of positive aspects of personality may be treated as an important limitation of the theory of Costa and McCrae. Caprara (2009) has proposed the existence of another important personality dimension named positive orientation (PO) defined as a basic tendency to perceive and evaluate positively oneself, one's future and one's life. The presently available data offer convincing evidence for the existence of three factors underlying the latent variable of PO, namely: self-esteem, satisfaction with life and optimism (Caprara, Steca, Alessandri, Abela, \& McWhinnie, 2010; Caprara \& Alessandri, 2014). According to Caprara's theory, PO fulfills important biological functions, i.e. people need it to grow, flourish and lead satisfactory and happy lives (Caprara, 2009; Alessandri, Caprara, \& Tisak, 2012).

Unfortunately, the above notions do not let us indisputably recognize $\mathrm{PO}$ as separate from the FFM and prove that it is necessary to measure PO independently, in addition to the FFM (Caprara et al., 2012a; Miciuk, Jankowski, Laskowska, \& Oleś, 2016). One can easily enumerate both differences and similarities between these two models. As the similarities are in question, both $\mathrm{PO}$ and personality traits are rather stable in the course of life and there exist both genetic and environmental factors underlying them (Caprara et al., 2009; McCrae \& Costa, 1990; Cobb-Clark \& Schurer, 2012). Moreover, positive orientation seems to be universal. There is some evidence that PO can be altered in quite a short term (e.g. procedures modifying generalized self-efficacy are quite convincing - Oleś et al., 2013; Caprara, Alessandri, \& Barbaranelli, 2010), and personality traits are changeable as well, though to a rather smaller extent and in the long run (this may often be observed when relatively distant points in one's lifespan are being compared - McCrae \& Costa, 1990). Among more radical differences between $\mathrm{PO}$ and personality traits, there is a notion that personality traits first of all refer to certain observable behaviors, whilst PO expresses primarily the inner states that are not so easy to observe for a person who does not experience them (Caprara, 2010). Moreover, personality traits are quite poor predictors of health and job success, especially if compared with PO (Pervin, 1996; Caprara, 2010; Alessandri et al., 2012). Another important gap between PO and the FFM is the mentioned difference in the ability to capture positivity encoded in personality (Caprara, 2010). Nevertheless, as will be described below, PO and FFM are correlated with each other.

There have been only a few studies investigating the relationship between PO and FFM so far. A broad study (Caprara et al., 2012a) conducted on two Italian, one Spanish and one Japanese sample showed that energy (equivalent of extraversion), emotional stability (reverse of neuroticism), conscientiousness, agreeableness and openness are all correlated with PO (Pearson's $r$ : .37 to $.44, .27$ to $.31, .24$ to $.28, .14$ to .29 , and .17 to .24 respectively; all $p<.01$ ). However, the latest research (Miciuk et al., 2016) conducted on a Polish sample showed that PO correlates only with neuroticism, extraversion and agreeableness (-.53 to $-.70, .57$ to .59 , .33 to .37 respectively; all Pearson's $r, p<.01$ ), and these results are probably attributable to some unspecified cultural differences. Moreover, in the same study, the canonical correlation analysis showed a sizeable affinity $(60 \%$ of common variance) between PO and FFM. On the one hand, this means that PO is at least partly included in the FFM. On the other hand, $40 \%$ of unexplained variance indicates the uniqueness of $\mathrm{PO}$ and partly justifies treating it as a separate psychological variable (Miciuk et al., 2016).

The current study portrays the next step in the investigation of the FFM-PO relationship. Taking into account the fact that personality traits are important predictors of a vast field of psychological functioning
Incremental validity of positive orientation 
Łukasz Roland Miciuk, Tomasz Jankowski, Piotr Oleś
(McCrae \& Costa, 2003), we put forward the following question: will the amount of explained variance grow if we include PO (in addition to personality traits) in the stepwise regression model? If yes, this would support the view that PO goes beyond the FFM. If not, this would at least make it harder to advocate the idea that PO is separate from the FFM. We have chosen the following variables to be predicted in the regression analysis: self-concept clarity, purpose in life and generalized self-efficacy - all linked to optimal functioning (e.g.: Emery, Walsh, \& Slotter, 2015; Van Dijk et al., 2014; Ryff \& Singer, 1998; Prairie, Scheier, Matthews, Chang, \& Hess, 2011; Zhao, Lei, He, Gu, \& Li, 2015).

Self-concept clarity is defined as "the extent to which the self-beliefs are clearly and confidently defined, internally consistent, and stable" (Campbell et al., 1996, p. 141). It is arguable that having a positive view of oneself (i.e. high self-esteem) supports integration of self-concept and hence promotes its clarity (like the reverse of "negative clarity" observed in depression). Being satisfied with one's life events and social relationships (i.e. high satisfaction with life) may translate to clarity as well (one may think like: "I have been rather satisfied with my life so far, so I probably pursue good actions and decisions, which proves that I probably know who I really am, what I really want, and what I really can do"), on condition that a person has an internal locus of control. Last but not least, optimism can be treated as an aspect of certainty ("I am certain that generally everything will be OK with me in the future"), and being certain about oneself may also correspond to having clear self-views.

Purpose in life is defined as "the extent to which a person engages in activities that are personally valued" (Scheier et al., 2006, p. 291). It seems reasonable to think that if you have high self-esteem, you represent a kind of authority to yourself, which means that if this is YOU who chooses your activities, they must be really important for you and worth engaging in. Furthermore, life satisfaction includes positive evaluation of one's activities directly in its definition, whilst optimism seems to promote engaging in them.

It is also theoretically justified that positive thinking about life, future and oneself (PO) corresponds to generalized self-efficacy defined as a general belief about one's efficacy in dealing with difficult situations and obstacles (Schwarzer, 1992). What we get as a result is positive thinking about oneself dealing with life in the future.

Summing this all up, in this study we postulated that if we predict certain psychological variables (particularly: self-concept clarity, purpose in life and generalized self-efficacy) on the basis of both PO and personality traits, this will lead to a greater amount of explained variance than if we enter personality traits as the only predictors into the regression model.

\section{PARTICIPANTS AND PROCEDURE}

\section{PARTICIPANTS}

The sample consisted of 130 participants ( 80 females and 50 males) at the mean age $M=24.84(S D=2.76$, $\min =19, \max =30$ ). They were all Polish students of different academic majors. They did not receive any compensation for their participation in the research.

\section{METHODS}

Eight questionnaires were used in this study. The rationale for using these particular methods was that they measure exactly the variables we wanted to investigate, and that they are Polish adaptations (or translations) of questionnaires approved and commonly used worldwide. The first four of the questionnaires described below have been traditionally used to measure PO and the three factors underling it (namely: self-esteem, satisfaction with life and optimism) (e.g. Caprara et al., 2012b; Alessandri et al., 2012).

The Self-Esteem Scale (SES) (Rosenberg, 1965; Polish adaptation: Dzwonkowska, Lachowicz-Tabaczek, \& Łaguna, 2008) consists of 10 items (the respondent ranks each of them on a 4-point scale from strongly agree to strongly disagree) and has satisfactory reliability (Cronbach's $\alpha$ coefficient: .83 for the Polish version and .77-.88 for the original version), as well as test-retest stability: .79-.88.

The Satisfaction with Life Scale (SWLS) (Diener, Emmons, Larson, \& Griffin, 1985; Polish adaptation: Juczyński, 2001) consists of 5 items and a respondent has to assess each of them on a 7-point scale. The SWLS has good psychometric parameters (Cronbach's $\alpha$ equals .81 for the Polish version and .87 for the original version; test-retest stability varies from .82 to .86 ).

The Life Orientation Test-Revised (LOT-R) (Scheier, Carver, \& Bridges, 1994; Polish adaptation: Juczyński, 2001) consists of 6 diagnostic items (plus 4 additional ones) and measures dispositional optimism defined as the extent to which one has positive expectations about one's future [C]. The LOT-R has a 5-point response scale and good reliability (Cronbach's $\alpha=.76$ ).

The Positivity Scale (P-SCALE) (Caprara et al., 2012a; Polish adaptation: Łaguna, Oleś, \& Filipiuk, 2011 ) is a brief measure of positive orientation treated as a single construct. It has 8 items, each of them to be assessed on a 5-point response scale (e.g.: "I am satisfied with my life", "I look forward to the future with hope and enthusiasm", "I feel I have many things to be proud of"). Cronbach's $\alpha$ varies from .77 to .84 and test-retest stability equals .84 , which proves the good psychometric parameters of the P-SCALE.

The NEO Five Factor Inventory (NEO-FFI) (Costa \& McCrae, 1992; Polish adaptation by Zawadzki, 
Strelau, Szczepaniak, \& Śliwińska, 1998) is a 60-item measure of the traits constituting the FFM. Reliability of the inventory is satisfactory (Cronbach's $\alpha$ : conscientiousness: .82; neuroticism: .80; extraversion: .77; openness: .68; agreeableness: .68), as is its validity (e.g. satisfactory coherence of the NEO-FFI results and observers' ratings; theoretically justified correlations with temperament and other domains of personality).

The Self-Concept Clarity Scale (SCC) (Campbell et al., 1996; Polish translation by Jankowski \& Oleś) consists of 12 items to be rated from 1 (strongly disagree) to 5 (strongly agree). Because of the lack of a full Polish adaptation of the SCC, the Polish translation was used. The original version of this measure has good psychometric parameters (Cronbach's $\alpha$ : .86 , test-retest reliability: .70-.79).

The Generalized Self-Efficacy Scale (GSES) (Schwarzer \& Jeruzalem, 1995; Polish adaptation: Schwarzer, Jeruzalem, \& Juczyński - Juczyński, 2001) is a 10 -item scale. The respondent has to rank each of them from 1 to 4 . Psychometric parameters are as follows: internal consistency (Cronbach's $\alpha$ ): .72, test-retest reliability: .52, split-half reliability: .49 . Moreover, the GSES has satisfactory construct validity and content validity.

The Life Engagement Test (LET) (Scheier et al., 2006 ) is a 10-item scale designed to measure the purpose in life. Because there is no full Polish adaptation of the LET, we used the translation by Back, Jankowski and Oleś. The original version of the LET has satisfactory reliability (Cronbach's $\alpha$ coefficient $=.72-.87$, test-retest reliability $=.61-.76)$, and its validity was confirmed mainly on the basis of its relation to other psychological variables.

\section{PROCEDURE}

The participants were recruited via snowball sampling, i.e. a non-probability sampling technique in which existing participants recruit other participants from among their acquaintances (Goodman, 1961). All of the participants agreed to their participation in the research. The time for completing papers was indefinite (everyone could work at her/his own pace). The whole sample collection process took several months.

\section{DATA ANALYSIS}

According to tradition, PO was represented in two ways in this study: as a score in the P-SCALE and as a factor score computed from the scores in the SES, the SWLS and the LOT-R (i.e. scales measuring the three variables underlying a latent factor of $\mathrm{PO}$ ). The statistical methods used included descriptive statis- tics, Pearson product-moment correlation coefficients (Pearson's $r$ ), exploratory factor analysis (EFA) (principal component analysis, PCA), and stepwise regression analysis.

\section{RESULTS}

Table 1 shows descriptive statistics and correlations between the variables. Positive orientation is represented twice: 1) as $\mathrm{PO}_{\mathrm{PS}}$, i.e. a score in the P-SCALE, and 2) as $\mathrm{PO}_{\mathrm{F}}$, i.e. a factor score computed from the scores in the SES, the SWLS and the LOT-R (EFA has resulted in one factor explaining $74 \%$ of the variance of the three mentioned ones, with their loads: .88 , .83 and .87 respectively). We also included scores in self-esteem, satisfaction with life and optimism separately to compare their effects with those of PO treated as a whole.

$\mathrm{PO}_{\mathrm{PS}}$ correlates with neuroticism, extraversion and conscientiousness and does not correlate with openness or agreeableness. $\mathrm{PO}_{\mathrm{F}}$ correlates with all five personality traits (with the lowest, but significant $r$ coefficient in the case of openness), while satisfaction with life alone does not correlate with agreeableness or openness. Moreover, PO correlates with all three variables chosen to be predicted in a regression analysis (i.e. self-concept clarity, generalized self-efficacy and purpose in life).

As can be seen in Table 2, the introduction of PO (in addition to the three personality traits correlating with PO, i.e. neuroticism, extraversion and conscientiousness) in a stepwise regression analysis led to the increase in the amount of explained variance of the predicted variables. Change in the amount of explained variance $\Delta R^{2}$ ranged from .02 to .14, depending on the measure of $\mathrm{PO}$ and the predicted variable. The highest incremental validity of PO can be observed for the purpose in life and PO represented by the score on the P-SCALE (see Table 3 for details), and the smallest for the same measure of $\mathrm{PO}$ and self-concept clarity. Inclusion of PO in the second step of regression analysis increased the amount of explained variance by at least $5 \%$ for each predicted variable (look at the last two columns in Table 2 and compare the highest $\Delta R^{2}$ coefficients in each line).

\section{DISCUSSION}

Firstly, consistently with the findings from the previous study on a Polish sample (Miciuk et al., 2016), $\mathrm{PO}_{\mathrm{PS}}$ correlated with only three personality traits: neuroticism, extraversion and conscientiousness. On the other hand, similarly to the findings of Caprara et al. (2012a), $\mathrm{PO}_{\mathrm{F}}$ correlates with all five personality traits (with the lowest, but significant $r$ coefficient in the case of openness). Generally speaking, we have
Incremental validity of positive orientation 


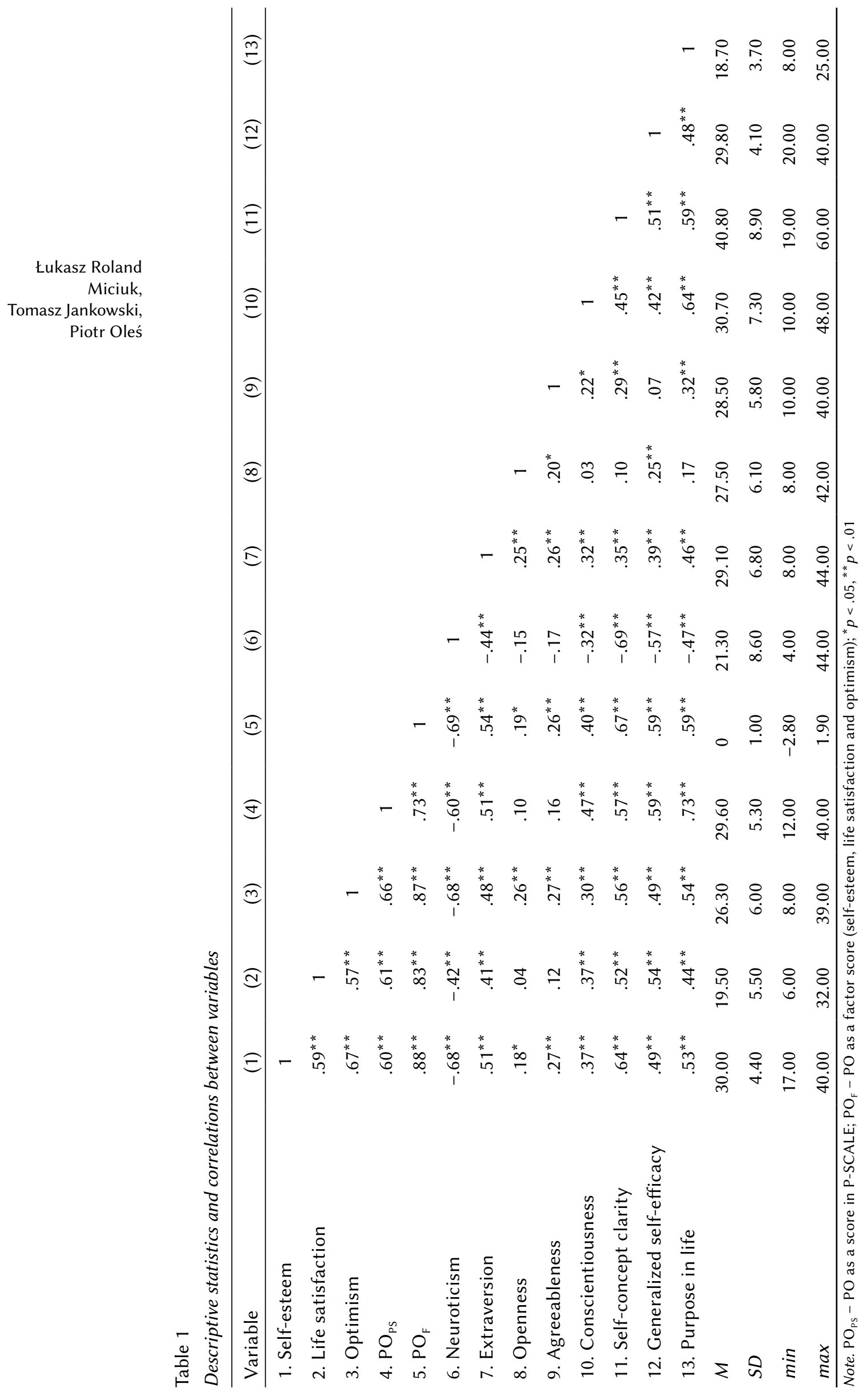


Table 2

Stepwise regression analyses: $R$ and $\Delta R$ coefficients

\begin{tabular}{|c|c|c|c|c|}
\hline \multirow[t]{2}{*}{ Predicted variables } & \multirow{2}{*}{$\begin{array}{c}\text { Step } 1 \\
\text { Predictors: } \\
\text { neuroticism, } \\
\text { extraversion, con- } \\
\text { scientiousness, } \\
\text { agreeableness } \\
\text { and openness }\end{array}$} & \multicolumn{3}{|c|}{$\begin{array}{c}\text { Step } 2 \\
\text { Predictors: neuroticism, extraversion, conscientiousness, } \\
\text { agreeableness, openness } \\
\text { and: }\end{array}$} \\
\hline & & $\begin{array}{l}\text { self-esteem, satis- } \\
\text { faction with life, } \\
\text { optimism }\end{array}$ & $\mathrm{PO}_{\mathrm{PS}}$ & $\mathrm{PO}_{\mathrm{F}}$ \\
\hline & $R^{2}$ & $\Delta R^{2}$ & $\Delta R^{2}$ & $\Delta R^{2}$ \\
\hline self-concept clarity & .53 & $.05^{* *}$ & $.02^{*}$ & $.05^{* *}$ \\
\hline purpose in life & .52 & $.04^{*}$ & $.14^{* *}$ & $.03^{* *}$ \\
\hline $\begin{array}{l}\text { generalized self- } \\
\text { efficacy }\end{array}$ & .40 & $.07^{* *}$ & $.05^{* *}$ & $.03^{* *}$ \\
\hline
\end{tabular}

obtained yet more evidence that PO shows affinity to a pattern of personality in which emotional stability (reverse of neuroticism), extraversion and conscientiousness seem crucial. Such an organization of traits is believed to be typical for unbeaten optimists and go-getters (Costa \& McCrae, 1992, 2000) and may be interpreted as a modified General Factor of Personality (Rushton \& Irwing, 2008).

Secondly, the results supported our hypothesis that predicting self-concept clarity, purpose in life and generalized self-efficacy on the basis of both PO and personality traits (namely: neuroticism, extraversion, conscientiousness, agreeableness, and openness) will lead to a greater amount of explained variance than when entering personality traits as the only predictors into the regression model. This effect can be consistently observed in the case of all three predicted variables and for two measures of $\mathrm{PO}$, regardless of different levels of the increments.

The theoretical implications of these findings are quite intriguing. They not only argue for separateness of the PO model and the FFM and for the legitimacy of measuring PO in addition to personality traits, but also cast some light on the presence of positivity in the FFM. Looking at Table 3, we can observe an interesting effect: the addition of PO in the second step of regression led to important changes in $\beta$ coefficients: the role of neuroticism and extraversion in predicting purpose in life became insignificant. This may be because the positive emotionality included in extraversion (and negative emotionality as its contrary, included in neuroticism) was taken over by $\mathrm{PO}$, which is more strongly saturated with positivity. Analogical effects were observed for the purpose in life and $\mathrm{PO}_{\mathrm{F}}$. This suggests that neurotic introverts may be lower in purpose in life as a result of neuroticism and extraversion being correlated with PO, which is the real predictor of purpose in life. In other words, the effect which had been re-
Table 3

Predicting purpose in life in stepwise regression analysis

\begin{tabular}{lcc}
\hline \multicolumn{2}{c}{ Predicted variable: purpose in life } \\
\hline Predictors & $\Delta R^{2}$ & $\beta$ \\
\hline Step 1 & $.54^{* * *}$ & \\
neuroticism & $-.21^{* *}$ \\
extraversion & $.17^{*}$ \\
conscientiousness & $.49^{* * *}$ \\
agreeableness & $.13^{*}$ \\
openness & .06
\end{tabular}

$F(5,124)=28.60, p<.001$

Step 2 $.14^{* * *}$

neuroticism $\quad .004$

extraversion $\quad .03$

conscientiousness $.35^{* * *}$

agreeableness $.14^{*}$

openness $\quad .07$

$\mathrm{PO}_{\mathrm{PS}} .52^{\text {** }}$

$F(6,123)=41.95, p<.001$

Note. $\mathrm{PO}_{\mathrm{PS}}-\mathrm{PO}$ as a score in P-SCALE; ${ }^{*} p \leq .05,{ }^{* *} p<.01$, ${ }^{* * *} p<.001$

vealed between purpose in life and neuroticism and extraversion in the first step of the regression analysis is in fact a spurious correlation - people low in $\mathrm{PO}$ are at the same time more neurotic, less extraverted and have a lower purpose in life. What is also interesting, in the case of all measures of PO, the second step of regression analyses always involved predictions on the basis of both PO and (some) trait(s). This is yet another argument for the separateness of $\mathrm{PO}$ and the FFM.
Incremental validity of positive orientation 
Łukasz Roland Miciuk,

Tomasz Jankowski, Piotr Oleś
Limitations of the described study include the following: sample imperfection (not very big and representing a student population from one country), limited number of the predicted variables, and the fact that this study is strictly correlational and based on self-reports. However, according to abundant empirical evidence (Chen, Watson, Biderman, \& Ghorbani, 2016; McCrae \& Costa, 1986; Uziel, 2010), self-reports of personality traits should not be perceived by design as contaminated with the need of social approval (e.g. because in many studies self-reports satisfactorily correlate with the ratings of others). Other data (Cyboron, 2014) suggest that the correlations (Pearson's $r$ ) between PO and the need for social approval (measured by questionnaire) are weak (.21 for SWLS, $p<.01 ; .25$ for SES, $p<.001$; n.s. for LOT-R).

Generally speaking, the obtained results are consistent with previous findings suggesting that PO and the FFM have much in common, but they are not identical (see also: Jibeen, 2014). However, our study is the first one advocating this notion by means of regression analysis, which conveys its unique contribution to the PO-FFM debate (Caprara et al., 2012a; Miciuk et al., 2016).

\section{CONCLUSIONS}

The aim of this study was to find new evidence in the debate on the separateness of the PO and FFM. Our hypothesis was that if we add PO as a predictor (an additional one to personality traits) in the second step of regression analysis, the amount of explained variance will increase. The results supported this hypothesis - taking PO into account allows for better prediction of such variables linked to optimal functioning as: purpose in life, generalized self-efficacy and self-concept clarity. This created a new argument for the legitimacy of educing and measuring positive orientation - a personality variable which may help us to explain some psychological phenomena, as the five major personality traits turn out to be insufficient predictors.

\section{ACKNOWLEDGEMENTS}

The authors acknowledge Magdalena Bilewicz for her participation in data collection.

\section{References}

Alessandri, G., Caprara, G. V., \& Tisak, J. (2012). The unique contribution of positive orientation to optimal functioning: Further explorations. European Psychologist, 17, 44-54. doi: 10.1027/1016-9040/ a000070
Alessandri, G., Vecchione, M., Tisak, J., Deiana, G., Caria, S., \& Caprara, G. V. (2012). The Utility of Positive Orientation in Predicting Job Performance and Organisational Citizenship Behaviors. Applied Psychology: An International Review, 61, 669-698.

Borgen, F. H., \& Lindley, L. D. (2003). Individuality and optimal human functioning: Interest, self-efficacy, and personality. In W. B. Walsh \& W. B. Walsh (eds.), Counseling psychology and optimal human functioning (pp. 55-91). Mahwah, NJ, US: Lawrence Erlbaum Associates Publishers.

Cain, S. (2012). Quiet: The Power of Introverts in a World That Can't Stop Talking. New York, NY: Crown.

Campbell, J. D., Trapnell, P. D., Heine, S. J., Katz, I. M., Lavallee, L. F., \& Lehman, D. R. (1996). Self-concept clarity: Measurement, personality correlates, and cultural boundaries. Journal of Personality and Social Psychology, 70, 141-156.

Caprara, G. V. (2009). Positive orientation: Turning potentials into optimal functioning. The European Health Psychologists. The bulletin of the European Health Psychology Society, 11, 46-48.

Caprara, G. V. (2010). W kierunku integracji teorii cech i społeczno-poznawczej [Trait Theory and Social Cognitive Theory towards an Integration]. In S. Nowosad \& B. Żurek (eds.), Barwy nauki. Nowoczesne technologie ICT w upowszechnianiu osiagnnięć nauki [Hues of Science. The Role of Information and Communications Technology ICT in Pupularization of Scientific Achievements] (pp. 315-336). Lublin: Towarzystwo Naukowe KUL.

Caprara, G. V., \& Alessandri, G. (2014). Optimal functioning: A review of current explorations of positive orientation. In S. Cooper, K. Ratele, S. Cooper, \& K. Ratele (eds.), Psychology serving humanity: Proceedings of the 30th International Congress of Psychology. Volume 2: Western psychology (pp. 202-214). New York, NY, US: Psychology Press.

Caprara, G. V., Alessandri, G., \& Barbaranelli, C. (2010). Optimal functioning: Contribution of self-efficacy beliefs to positive orientation. Psychotherapy and Psychosomatics, 79, 328-330. doi: 10.1159/000319532

Caprara, G. V., Alessandri, G. A., Eisenberg, N., Kupfer, A., Steca, P., Caprara, M. G., Yamaguchi, S., Fukuzawa, A., \& Abela, J. (2012a). The Positivity Scale. Psychological Assessment, 24, 701-712.

Caprara, G. V., Alessandri, G., Trommsdorff, G., Heikamp, T., Yamaguchi, S., \& Suzuki, F. (2012b). Positive orientation across three cultures. Journal of Cross-Cultural Psychology, 43, 77-83.

Caprara, G. V., Fagnani, C., Alessandri G., Steca P., Gigantesco, A., Cavalli Sforza, L. L., \& Stazi M. A. (2009). Human optimal functioning: The genetics of positive orientation towards self, life, and the future. Behaviour Genetics, 39, 277-284. 
Caprara, G. V., Steca, P., Alessandri, G., Abela, J. R., \& McWhinnie, C. M. (2010). Positive orientation: explorations on what is common to life satisfaction, self-esteem, and optimism. Epidemiologia $E$ Psichiatria Sociale, 19, 63-71.

Carlotta, D., Krueger, R. F., Markon, K. E., Borroni, S., Frera, F., Somma, A., Maffei, C., \& Fossati, A. (2015). Adaptive and maladaptive personality traits in high-risk gamblers. Journal of Personality Disorders, 29, 378-392. doi: 10.1521/pedi_2014_28_164

Chen, Z., Watson, P. J., Biderman, M., \& Ghorbani, N. (2016). Investigating the properties of the general factor (M) in bifactor models applied to Big Five or HEXACO data in terms of method or meaning. Imagination, Cognition and Personality, 35, 216-243. doi: 10.1177/0276236615590587

Chen-Ming, C., \& Ying-Wen, L. (2009). Personality traits and personal and organizational inducements: Antecedents of workaholism. Social Behavior \& Personality: An International Journal, 37, 645-660.

Cobb-Clark, D. A., \& Schurer, S. (2012). The stability of big-five personality traits. Economics Letters, 115, 11-15. doi: 10.1016/2011.11.015.

Costa, P. T., Jr., \& McCrae, R. R. (1992). The NEO-Five Personality Inventory manual. Odessa, FL: Psychological Assessment Resources.

Costa, P. T., Jr., \& McCrae, R. R. (2000). Revised NEO Personality Inventory. Interpretive Report. Lutz, FL: Psychological Assessment Resources, Inc.

Cyboroń, N. (2014). Orientacja pozytywna - korelaty i uwarunkowania [Correlates and Determinants of Positive Orientation] (Unpublished master's thesis). The John Paul II Catholic University of Lublin, Lublin, Poland.

Diener, E., Emmons, R. A., Larson, R. J., \& Griffin, S. (1985). The Satisfaction with Life Scale. Journal of Personality Assessment, 49, 71-75.

Donaldson, S. I., Dollwet, M., \& Rao, M. A. (2015). Happiness, excellence, and optimal human functioning revisited: Examining the peer-reviewed literature linked to positive psychology. The Journal of Positive Psychology, 10, 185-195. doi: 10.1080/17439760.2014.943801

Dzwonkowska, I., Lachowicz-Tabaczek, K., \& Łaguna, M. (2008). Samoocena i jej pomiar. Skala samooceny SES M. Rosenberga [Self-esteem and its measurement. The Rosenberg Self-Esteem Scale SES]. Warszawa: Pracownia Testów Psychologicznych PTP.

Egan, S. J., Piek, J. P., \& Dyck, M. J. (2015). Positive and negative perfectionism and the big five personality factors. Behaviour Change, 32, 104-113. doi: 10.1017/bec.2015.3

Emery, L. F., Walsh, C., \& Slotter, E. B. (2015). Knowing who you are and adding to it: Reduced self-concept clarity predicts reduced self-expansion. Social Psychological And Personality Science, 6, 259-266. doi: 10.1177/1948550614555029
Goodman, L. A. (1961). Snowball sampling. Annals of Mathematical Statistics, 32, 148-170.

Jibeen, T. (2014). Personality traits and subjective well-being: Moderating role of optimism in university employees. Social Indicators Research, 118, 157-172. doi: 10.1007/s11205-013-0416-6

Juczyński, Z. (2001). Narzędzia pomiaru w promocji i psychologii zdrowia [Measurement instruments in health promotion and health psychology]. Warszawa: Pracownia Testów Psychologicznych PTP.

Łaguna, M., Oleś, P., \& Filipuk, D. (2011). Orientacja pozytywna i jej pomiar: Polska adaptacja Skali Orientacji Pozytywnej [Positive Orientation and its measurement: Polish adaptation of the Positivity Scale]. Studia Psychologiczne, 49, 47-57.

McCrae, R. R., \& Costa, P. T. (1986). Social desirability scales: More substance than style. Journal of Consulting and Clinical Psychology, 51, 882-888. doi: 10.1037/0022- 006X.51.6.882

McCrae, R. R., \& Costa, P. T. (1987). Validation of the five-factor model of personality across instruments and observers. Journal of Personality and Social Psychology, 52, 81-90.

McCrae, R. R., \& Costa, P. T. (1990). Personality in adulthood. New York: The Guildford Press.

McCrae, R. R., \& Costa, P. T. (2003). Personality in adulthood: A five-factor theory perspective ( $2^{\text {nd }}$ ed. $)$. New York: Guilford.

Miciuk, Ł. R., Jankowski, T., Laskowska, A., \& Oleś, P. (2016). Postive Orientation and the Five-Factor Model. Polish Psychological Bulletin, 47, 141-148. doi: 10.1515/ppb-2016-0016

Oleś, P. K., Alessandri, G., Oleś, M., Bak, W., Jankowski, T., Laguna, M., \& Caprara, G. V. (2013). Positive orientation and generalized self-efficacy. Studia Psychologica, 55, 47-58.

Pervin, L. A. (1996). The science of personality. New York: John Wiley \& Sons, Inc.

Prairie, B. A., Scheier, M. F., Matthews, K. A., Chang, C. H., \& Hess, R. (2011). A higher sense of purpose in life is associated with sexual enjoyment in midlife women. Menopause (New York, N.Y.), 18, 839-844. doi: 10.1097/gme.0b013e31820befca

Rosenberg, M. (1965). Society and the adolescent self-image. Princeton, NJ: Princeton University Press.

Rushton, J. P., \& Irwing, P. (2008). A General Factor of Personality (GFP) from two mata-analyses of the Big Five: Digman (1997) and Mount, Barrick, Scullen, and Rounds (2005). Personality and Individual Differences, 45, 679-683.

Ryff, C. D., \& Singer, B. (1998). The role of purpose in life and personal growth in positive human health. In P. P. Wong, P. S. Fry, P. P. Wong, \& P. S. Fry (eds.), The human quest for meaning: $A$ handbook of psychological research and clinical applications (pp. 213-235). Mahwah, NJ, US: Lawrence Erlbaum Associates Publishers.

Scheier, M. F., Carver, C. S., \& Bridges, M. W. (1994). Distinguishing optimism from neuroticism (and
Incremental validity of positive orientation 
Łukasz Roland Miciuk, Tomasz Jankowski, Piotr Oleś trait anxiety, self-mastery, and self-esteem): A reevaluation of the Life Orientation Test. Journal of Personality and Social Psychology, 67, 1063-1078.

Scheier, M. F., Wrosch, C., Baum, A., Cohen, S., Martire, L. M., Matthews, K. A., Schulz, R., \& Zdaniuk, B. (2006). The Life Engagement Test: Assessing purpose in life. Journal of Behavioral Medicine, 29, 291-298.

Schwarzer, R. (ed.). (1992). Self-efficacy. Thought control of action. Washington, DC: Hemisphere.

Schwarzer, R., \& Jerusalem, M. (1995). Generalized Self-Efficacy Scale. In J. Weinman, S. Wright, \& M. Johnston (eds.), Measures in health psychology: A user's portfolio. Causal and control beliefs (pp. 35-37). Windsor: UK: Nfer-Nelson.

Sheldon, K. M., Cheng, C., \& Hilpert, J. (2011). Understanding Well-Being and Optimal Functioning: Applying the Multilevel Personality in Context (MPIC) Model. Psychological Inquiry, 22, 1-16. doi: 10.1080/1047840X.2011.532477

Snyder, C. R., \& Lopez, S. J. (eds.). (2002). The handbook of positive psychology. New York: Oxford University Press.

Uziel, L. (2010). Rethinking social desirability scales: From impression management to interpersonally oriented self-control. Perspectives on Psychological Science, 5, 243-262. doi: 10.1177/1745691610369465

Van Dijk, M. A., Branje, S., Keijsers, L., Hawk, S. T., Hale, W. I., \& Meeus, W. (2014). Self-concept clarity across adolescence: Longitudinal associations with open communication with parents and internalizing symptoms. Journal of Youth and Adolescence, 43, 1861-1876. doi: 10.1007/s10964-0130055-x

Zawadzki, B., Strelau, J., Szczepaniak, P., \& Śliwińska, M. (1998). Inwentarz Osobowości NEO-FFI Costy i McCrae: Adaptacja polska. Podręcznik [NEO Five Factor Inventory by Costa \& McCrae: Polish adaptation. Handbook]. Warszawa: Pracownia Testów Psychologicznych Polskiego Towarzystwa Psychologicznego.

Zhao, F., Lei, X., He, W., Gu, Y., \& Li, D. (2015). The study of perceived stress, coping strategy and self-efficacy of Chinese undergraduate nursing students in clinical practice. International Journal of Nursing Practice, 21, 401-409. doi: 10.1111/ ijn. 12273 